\title{
SOSIALISASI DAN PELATIHAN PEMBUATAN PUPUK ORGANIK CAIR DARI LIMBAH RUMAH TANGGA UNTUK PKK KAMPUNG AIMO
}

\section{Wiji Safitri*}

\author{
Fakultas Teknik \& Pertanian, Universitas Nani Bili Nusantara,
} email: wijisafitri5@gmail.com

\begin{abstract}
ABSTRAK
PKK Kampung AIMO menghadapi permasalahan yaitu terbatasnya pengetahuan dan teknologi budidaya pertanian. Hal ini yang menjadi penyebab mengapa sampai sekarang PKK Kampung AIMO tidak berjalan dengan baik. Masalah tersebut dipecahkan dengan dilakukan sosialisasi teknologi budidaya tanaman. Kegiatan sosialisasi terlebih dulu dilakukan oleh Adlian, S.P., M.Sc. "Pelatihan Penanaman Sayuran Organik di Pekarangan Rumah" sehingga menjadi cikal bakal program PKK Kampung AIMO yaitu "Pemanfaaatan Lahan Pekarangan Rumah dengan Sayuran untuk Pemenuhan Gizi Keluarga". Kegiatan pengabdian masyarakat dengan tema "Sosialisasi dan Pelatihan Pembuatan Pupuk Organik Cair dari Limbah Rumah Tangga untuk PKK Kampung Aimo, Kab. Sorong" merupakan kegiatan lanjutan yang dilakukan untuk mendukung program kerja PKK Kampung Aimo. Kegiatan Sosialisasi dan Pelatihan Pembuatan Pupuk Organik Cair dari Limbah Rumah Tangga memberikan hasil : 1). Anggota PKK Kampung AIMO mengetahui pembuatan pupuk organik cair dari limbah rumah tangga., 2). Kampung AIMO menjadi Kampung Binaan Fakultas Teknik \& Pertanian dan menjadi wadah pertukaran ilmu dan teknologi antara masyarakat dan Perguruan Tinggi., 3). Anggota PKK Kampung AIMO sudah mengetahui cara membuat Pupuk Organik Cair dari Limbah Rumah Tangga dan mampu sharing terhadap sesama anggotanya., 4). Penanaman sayur organik di pekarangan rumah dengan teknologi pemupukan organik dari limbah rumah tangga menjadi program kerja PKK Kampung AIMO.
\end{abstract}

Kata Kunci: Pupuk organik cair, Limbah rumah tangga, Lahan pekarangan rumah, Sayur organik, Kampung AIMO

\section{ABSTRACT}

PKK Kampung AIMO has the main current problem are knowledge and technology of agricultural cultivation limited. This situation causes the program PKK Kampung AIMO doesn't work as usual. The problem solving for thus is the socialization of agricultural cultivation technology which has been done by Adlian S.P., M.Sc "Organic Vegetable Planting Training in Home Yard"and the pioneer of PKK Kampung AIMO Program is "Utilization of Home Yard Land with Vegetables for Family Nutrition Fulfillmen". The result of training and socialization about "Making Liquid Organic Fertilizer from Household Waste” consist of 1). The member of PKK Kampung AIMO knowing to make liquid fertilizer organic from household waste, 2). Kampung Aimo and Faculty of Enggineering and Agriculture UNBN building cooperation to sharing knowledge and technology, 3). The member of PKK Kampung AIMO knowing to sharing knowledge with others, 4). Organic vegetables planting in home yard with liquid organic fertilization from household waste become a program in PKK Kampung AIMO.

Keywords: Liquid organic fertilizer, Household waste, Homeyard land, Organic vegetable, AIMO village 


\section{PENDAHULUAN}

Analisis Situasi

Budidaya Sayuran di pekarangan rumah bukan merupakan hal baru. Praktek demikian sudah lama dipraktekkan terutama di pedesaan. Akhir - akhir ini, praktek demikian semakin ditinggalkan dan lahan pekarangan di pedesaan banyak dibiarkan terlantar dan gersang (Balitbangtan Sulsel, 2018).

Kampung Aimo adalah salah satu kampung yang berada di distrik Aimas, Kabupaten Sorong dengan jumlah penduduk 110 Kepala Keluarga [1]. Hasil Survei Lapangan sejak tanggal 1 - 7 Maret 2019 diperoleh data bahwa rata - rata warga Aimo $85 \%$ petani, $10 \%$ pelajar, dan $5 \%$ pegawai pemerintah. Dari $10 \%$ pelajar tersebut tergolong ke dalam kelompok pelajar SD, SMP, SMA, dan Sarjana. Sementara 5\% pegewai pemerintah tergolong ke dalam pegawai aparatur desa dan pegawai aparatur pemerintah kabupaten. Oleh karena itu, PKK yang ada di Kampung Aimo belum memiliki program kerja khusus sehingga belum aktif.

Penyuluhan Pengabdian Masyarakat untuk PKK Kampung Aimo terlebih dahulu di awali oleh Dosen Agroteknologi Universitas Nani Bili, Adlian S.P., M.Sc dengan tema "Pelatihan Penanaman Sayuran Organik di Pekarangan Rumah" pada tanggal 9 Maret 2019. Kegiatan tersebut sekaligus sebagai cikal bakal program kerja PKK Kampung Aimo. Pertemuan anggota PKK dilakukan setiap seminggu sekali dengan program

kerja

"Pemanfaaatan

Lahan

Pekarangan Rumah dengan Sayuran untuk Pemenuhan Gizi Keluarga”. Kegiatan pengabdian masyarakat dengan tema "Sosialisasi dan Pelatihan Pembuatan Pupuk Organik Cair dari Limbah Rumah Tangga untuk PKK Kampung Aimo, Kab. Sorong” merupakan kegiatan lanjutan yang dilakukan untuk mendukung program kerja PKK Kampung Aimo.

Pupuk Organik adalah bahan organik yang umumnya berasal dari tumbuhan atau hewan, yang ditambahkan secara spesifik sebagai sumber hara [2]. Peraturan Menteri Pertanian No. 28/Permentan/SR.130/5/2009 menyatakan bahwa pupuk organik adalah pupuk yang berasal dari sisa tanaman dan kotoran hewan yang telah melalui proses rekayasa, berbentuk padat atau cair dan dapat diperkaya dengan bahan mineral alami atau mikroba yang bermanfaat memperkaya hara, bahan organik tanah, memperbaiki sifat fisik, kimia, dan biologi tanah. Pupuk organik sangat berpengaruh terhadap pertumbuhan, perkembangan, dan kesehatan tanaman [3].

Dari hasil survey lapangan, masyarakat Kampung Aimo tidak ada yang bekerja sebagai peternak baik pekerjaan utama maupun sampingan. Oleh karena itu, sebagai bahan pertimbangan untuk pembuatan pupuk organik dipilihlah limbah rumah tangga yang memang belum dimanfaatkan dengan baik. Menurut [4] pupuk organik cair lebih efektif untuk mendukung pertumbuhan tanaman, yaitu perangsang pertumbuhan. Penggunaan 
limbah rumah tangga untuk pupuk organik cair merupakan solusi yang ditawarkan untuk PKK Kampung AIMO. Dengan diadakannya sosialisasi dan pelatihan pembuatan pupuk organik dari limbah rumah tangga ini, diharapkan masyarakat dapat menghasilkan sayur dan berkualitas untuk dikonsumsi keluarganya. Lebih lanjut, masyarakat dapat membuat pupuk organik untuk tanaman sayuran yang ditanam di kebun untuk mendapatkan sayuran organik yang sehat, sehingga dapat meningkatkann pendapatan masyarakat.

\section{Permasalahan Mitra}

Permasalahan utama yang dihadapi PKK Kampung AIMO saat ini adalah terbatasnya pengetahuan dan teknologi budidaya pertanian. Hal ini yang menjadi penyebab mengapa sampai sekarang PKK Kampung AIMO tidak berjalan dengan baik.

Tenaga ahli ataupun pendidik di bidang pertanian yang belum masuk ke Kampung AIMO, menyebabkan PKK Kampung AIMO hanya berjalan tanpa ada kemajuan yang berarti. Disamping keterbatasan pengetahuan dan teknologi, kelembagaan PKK Kampung AIMO juga belum optimal sehingga yang terjadi anggota PKK sebatas bekerja bersama untuk menanam suatu komoditas hortikultura. Teknologi budidaya untuk meningkatkan hasil pertanian belum berkembang. Dengan demikian, kemajuan bersama anggota kelompok dalam hal meningkatkan produktivitas hasil pertanian belum tercapai dengan terbentuknya kelompok PKK Kampung AIMO.

\section{Solusi yang Ditawarkan}

Masalah sebagaimana yang dijelaskan diatas, ditawarkan untuk diselesaikan dengan alternatif sebagai berikut:

a. Memberikan sosialisasi teknologi budidaya yang mudah dilaksanakan oleh masyarakat untuk meningkatkan produksi hasil pertanian masyarakat, seperti pembuatan pupuk cair dari limbah rumah tangga.

b. Memberikan pelatihan terhadap sosialisasi yang dilaksanakan.

c. Memberikan pelatihan penguatan kelembagaan kelompok PKK Kampung AIMO menuju kelompok yang berdaya saing.

\section{Target Keluaran}

Sesuai dengan rencana kegiatan maka dapat dijelaskan target keluaran seperti Tabel 1 berikut ini. 
Tabel 1. Target Keluaran dari Kegiatan yang akan dilaksanakan.

\begin{tabular}{|c|c|c|c|c|}
\hline No. & Permasalahan Mitra & Solusi & Kegiatan & Keluaran \\
\hline 1. & $\begin{array}{l}\text { Belum memiliki } \\
\text { pengetahuan tentang } \\
\text { teknologi budidaya }\end{array}$ & $\begin{array}{l}\text { Sosialisasi } \\
\text { teknologi } \\
\text { budidaya tepat } \\
\text { guna, } \\
\text { "Pembuatan } \\
\text { Pupuk Organik } \\
\text { Cair dari } \\
\text { Limbah Rumah } \\
\text { Tangga". }\end{array}$ & $\begin{array}{l}\text { Metode } \\
\text { Sosialisasi } \\
\text { dengan } \\
\text { Presentasi }\end{array}$ & $\begin{array}{lr}\text { 1. } 75 \% \text { anggota } & \text { PKK } \\
\text { Kampung AIMO } \\
\text { mengetahui } \\
\text { pembuatan pupuk } \\
\text { organik cair dari } \\
\text { limbah rumah tangga. } \\
\text { 2. PKK Kampung } \\
\text { AIMO menjadi wadah } \\
\text { sharing pengetahuan } \\
\text { teknologi budidaya } \\
\text { dari r Perguruan } \\
\text { Tinggi. }\end{array}$ \\
\hline 2. & $\begin{array}{l}\text { Belum mampu } \\
\text { membuat dan } \\
\text { melakukan teknologi } \\
\text { budidaya pertanian } \\
\text { tepat guna. }\end{array}$ & $\begin{array}{l}\text { Pelatihan } \\
\text { "Pembuatan } \\
\text { Pupuk Organik } \\
\text { Cair dari } \\
\text { Limbah Rumah } \\
\text { Tangga" }\end{array}$ & $\begin{array}{l}\text { Metode } \\
\text { Pelatihan, } \\
\text { Bimbingan, } \\
\text { dan Konsultasi }\end{array}$ & $\begin{array}{l}\text { Semua anggota PKK } \\
\text { Kampung AIMO } \\
\text { mampu membuat pupuk } \\
\text { organik cair sederhana } \\
\text { dari limbah rumah } \\
\text { tangga. }\end{array}$ \\
\hline 3. & $\begin{array}{l}\text { Belum kuatnya sistem } \\
\text { kelembagaan yang ada }\end{array}$ & $\begin{array}{l}\text { Perlu pembinaan } \\
\text { program pokok } \\
\text { PKK yang akan } \\
\text { dicapai setiap } \\
\text { periode dan } \\
\text { menerapkannya } \\
\text { di semua kebun } \\
\text { usaha pertanian } \\
\text { setiap anggota } \\
\text { PKK. }\end{array}$ & $\begin{array}{l}\text { Metode } \\
\text { Bimbingan dan } \\
\text { Konsultasi }\end{array}$ & $\begin{array}{l}\text { PKK Kampung AIMO } \\
\text { memiliki Program } \\
\text { Pokok yang dijalankan } \\
\text { dengan output } \\
\text { meningkatnya produksi } \\
\text { pertanian masyarakat. }\end{array}$ \\
\hline
\end{tabular}

METODE PELAKSANAAN KEGIATAN

Guna membantu menyelesaikan permasalahan pada kelompok PKK Kampung AIMO digunakan metode Pendidikan Masyarakat, meliputi tiga pendekatan yang dilakukan yaitu sosialisasi, pelatihan, serta bimbingan (pendampingan). Sosialisasi dilakukan dengan metode ceramah dan diskusi, pelatihan dengan metode praktek lapangan, serta bimbingan dilakukan dengan metode konsultasi baik secara langsung/tatap muka atau via media telepon dan cara - cara lain yang mungkin

dilakukan. Untuk kesinambungan
pembinaan, maka sebaiknya Kampung AIMO mejadi Kampung Binaan Fakultas Teknik dan Pertanian Universitas Nani Bili Nusantara.

\section{Tahapan Kegiatan}

Tahapan kegiatan dibagi dalam tiga kelompok utama, yaitu Persiapan, Pelaksanaan, dan Evaluasi \& Laporan. Secara umum, kegiatan yang dilakukan pada setiap tahapan kegiatan dapat dilihat pada Tabel 2. 
Tabel 2. Tahapan Kegiatan Pengabdian Masyarakat yang dilakukan

\begin{tabular}{|c|c|c|}
\hline No. & Tahapan & Kegiatan \\
\hline 1. & Persiapan & $\begin{array}{l}\text { 1. Sosialisasi dengan Pihak Kepala Kampung AIMO. } \\
\text { 2. Menghubungi kelompok PKK Kampung AIMO untuk } \\
\text { membicarakan jadwal dan persiapan. } \\
\text { 3. Menyusun materi sosialisasi dan peralatan pelatihan. } \\
\text { Alat dan bahan } \\
\text { Ember, Limbah Rumah Tangga, Air, Batu, Karung, EM4, Larutan } \\
\text { Gula } \\
\text { 4. Persiapan untuk Pelaksanaan. }\end{array}$ \\
\hline 2. & Pelaksanaan & $\begin{array}{l}\text { 1. Melakukan sosialisasi dengan metode Presentasi dengan media } \\
\text { interaktif. } \\
\text { 2. Melakukan pelatihan dengan praktek lapangan langsung dibantu } \\
\text { mahasiswa Program Studi Agroteknologi. }\end{array}$ \\
\hline 3. & $\begin{array}{l}\text { Evaluasi \& } \\
\text { Laporan }\end{array}$ & $\begin{array}{l}\text { 1. Evaluasi Kegiatan } \\
\text { 2. Laporan Kegiatan }\end{array}$ \\
\hline
\end{tabular}

\section{HASIL DAN PEMBAHASAN}

\section{Pelaksanaan Kegiatan}

Kegiatan pengabdian masyarakat berlangsung lancar di kelompok PKK Kampung AIMO, Distrik Aimas, Kabupaten Sorong, Papua Barat. Pengabdian masyarakat Sosialisasi dan Pelatihan Pembuatan Pupuk Organik Cair dari Limbah Rumah Tangga atas biaya dari LP2M (Lembaga Penelitian dan Pengabdian Masyarakat) Universitas Nani Bili Nusantara.

Kegiatan penjajakan lokasi pengabdian dilakukan pada 27 Maret - 6 April 2019. Kegiatan yang dilakukan yakni menemui anggota kelompok PKK Kampung AIMO untuk membicarakan kegiatan yang perlu dilakukan berdasarkan kegiatan pengabdian masyarakat sebelumnya oleh Adlian S.P., M.Sc dengan tema "Pelatihan Penanaman Sayuran Organik di Pekarangan Rumah" pada tanggal 9 Maret 2019. Tema yang dipilih untuk kegiatan lanjutan yakni pembuatan pupuk untuk Sayuran Pekarangan Rumah. Berdasarkan analisis situasi masyarakat, teknologi budidaya yang mudah untuk dilakukan yakni Pembuatan Pupuk dari Limbah Rumah Tangga. Mengingat tanaman sayuran yang relatif berumur singkat, penggunaan pupuk organik cair lebih mampu bekerja lebih efektif karena mudah meresap dalam tanah sehingga tanaman sayuran tumbuh dengan baik.

Kegiatan pengabdian masyarakat di kelompok PKK Kampung AIMO Distrik Aimas Kabupaten Sorong Papua Barat dilaksanakan meliputi kegiatan sebagai berikut :

1). Sosialisasi pupuk organik, ragam jenis pupuk organik, dan pembuatan pupuk organik cair dari limbah rumah tangga.

2).Pelatihan pembuatan pupuk organik cair dari limbah rumah tangga. 
3).Pelatihan pelasanaan kegiatan atau program kerja yang dilakukan di PKK Kampung AIMO.

4).Evaluasi pelatihan pembuatan pupuk organik cair dari limbah rumah tangga.

Dalam tahapan ini dilakukan tanya jawab dan diskusi dengan anggota PKK Kampung AIMO terkait pupuk organik cair dari limbah rumah tangga. Kegiatan dilakukan dengan metode Pendidikan Masyarakat untuk meningkatkan pengetahuan masyarakat akan pentingnya sayuran sehat untuk keluarga dan memanfaatkan limbah rumah tangga menjadi lebih bermanfaat.

Kegiatan Sosialisasi dan Pelatihan Pembuatan Pupuk Organik Cair dari Limbah Rumah Tangga memberikan hasil :

\section{1). Anggota PKK Kampung AIMO} mengetahui pembuatan pupuk organik cair dari limbah rumah tangga.

2).Kampung AIMO menjadi Kampung Binaan Fakultas Teknik \& Pertanian dan menjadi wadah pertukaran ilmu dan teknologi antara masyarakat dan Perguruan Tinggi.

3). Anggota PKK Kampung AIMO sudah mengetahui cara membuat Pupuk Organik Cair dari Limbah Rumah Tangga dan mampu sharing terhadap sesame anggotanya.

4).Penanaman sayur organik di pekarangan rumah dengan teknologi pemupukan organik dari limbah rumah tangga menjadi program kerja PKK Kampung AIMO.

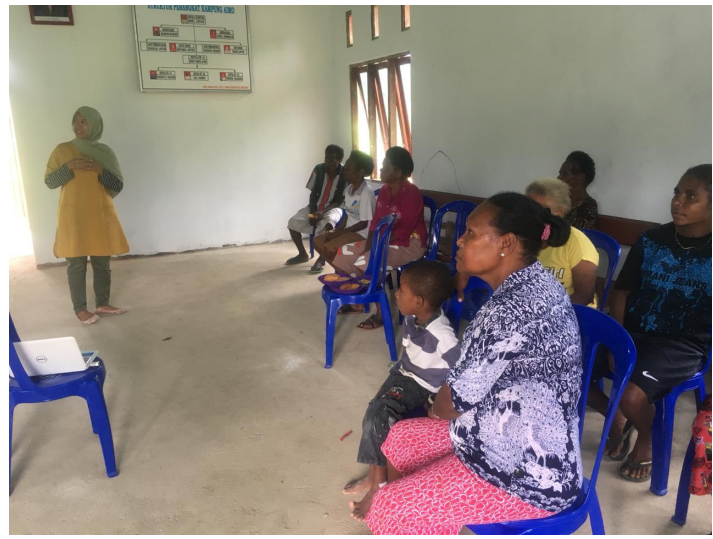

Gambar 1. Pemateri mensosialisasikan Pembuatan Pupuk Organik Cair dari Limbah Rumah Tangga

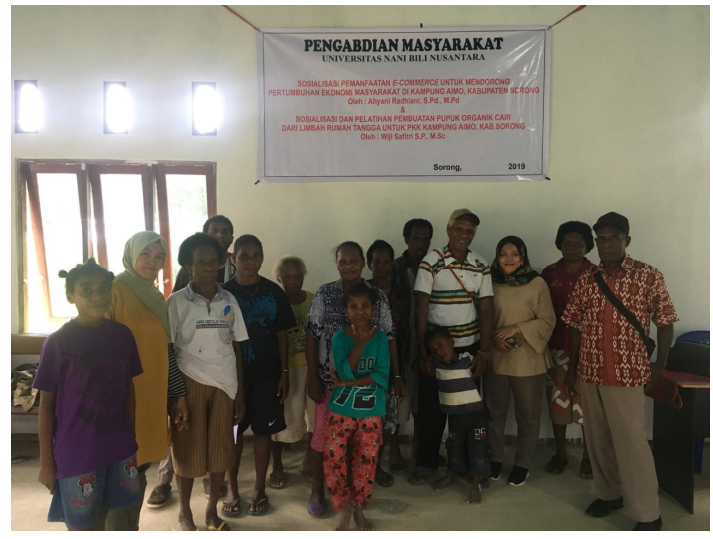

Gambar 2. Tim Pelatihan dan Sosialisasi beserta Anggota PKK Kampung AIMO

\section{SARAN}

Saran dari tim Pengabdian Masyarakat Pembuatan Pupuk Organik Cair dari Limbah Rumah Tangga yaitu perlu kegiatan berkelanjutan terkait pendampingan terhadap masyarakat untuk meningkatkan hasil budidayanya dengan penggunaan teknologi tepat guna.

\section{UCAPAN TERIMA KASIH}

Diucapkan terima kasih kepada Ketua Lembaga Penelitian dan Pengabdian Universitas Nani Bili Nusantara bapak Folce 
Elden Palyama, S.H., M.H., Bapak Ahmad

Rizal N.K., S.T., M.Pd dari Prodi Teknik

Mesin, Ibu Ahyani Radhiani, S.Pd., M.Pd.

dari Prodi Teknik Informatika atas dukungan

moril dan bantuan materi yang diberikan

sehingga terlaksananya kegiatan pengandian ini.

\section{DAFTAR PUSTAKA}

[1] Anto, M. 2019. Wawancara Pribadi. Kabupaten Sorong.

[2] Sutanto, R. 2002. Penerapan Pertanian Organik. Penerbit Kanisius. Yogyakarta.
[3] Suriawiria, U. 2003. Mikrobiologi Air dan Dasar - Dasar Pengolahan Buangan secara Biologis. PT Alumni. Bandung.

[4] Sundari, I., Maruf, W.F., Dewi, E.N. 2014. The Utilization of EM4 Bioactivator and Fish Flour to Specifications of Liquid Organic Gracilaria sp. Seaweed Fertilizer. Jurnal Pengolahan dan Bioteknologi Hasil Perikanan. 3( 3) : 88 - 94.

[5] Anonim. 2018. Budidaya Sayuran di Lahan Pekarangan. BPTP Balitbangtan Sulawesi Selatan. Makassar. 